\title{
Insights for Community Outreach Building to Promote Lifelong Learning With Higher Education Alumni in Chile
}

\author{
Paula A. Charbonneau-Gowdy, $\mathrm{PhD}$ \\ Universidad Andres Bello, Santiago, Chile \\ Héctor A. Magaña, MA \\ Universidad Andres Bello, Santiago, Chile
}

Contact: paula.charbonneau@unab.cl

\begin{abstract}
Despite conclusive evidence from high performing higher education (HE) institutions worldwide demonstrating the benefits of strong alumni relations, institutions in many evolving countries often neglect their graduates. And this, despite rapid advances in technology that can support ongoing relations. The objective of our year-long project was to address this neglect. We (re)connected with 220 English pedagogy alumni through a digital newsletter. The newsletter provided a forum for building community and mediating professional development among graduates and current faculty. Our qualitative mini case study focused on uncovering the emotions, perspectives and needs of former students through the lens of sociocultural and identity theory using a Likert scale questionnaire, field notes and writing-based interviews to collect data. Positive gains from this initiative were evidenced in clear signs of alumni's increased recognition of their agency in mediating empowered professional identities through continuous learning. This recognition accompanied a trajectory of their investment in their professional development, characterized by a sense of affinity, then engagement with and support of the institution and community building. We believe these findings speak volumes of the potential of such outreach for all stakeholders in education, including the society at large.
\end{abstract}

Keywords: lifelong learning; alumni community outreach; continuing education; 21st-century professionalism

Submitted: March 10, 2020 | Accepted: March 22, 2020 | Published: May 21, 2020

\section{Recommended Citation}

Charbonneau-Gowdy, P., \& Magaña, H. A. (2020). Insights for community outreach building to promote lifelong learning with higher education alumni in Chile. Higher Learning Research Communication, 10(1), 37-61. https://doi.org/10.18870/hlrc.v10i1.1178 


\section{Introduction}

Higher education (HE) institutions in evolving countries have traditionally viewed their key role in promoting tertiary education for the majority of their country's population, for whom this level of education has been historically out of reach. This democratizing role has come with a host of challenges, in particular in preventing attrition and ensuring higher completion rates. In this preoccupation with "getting them (i.e., students) through," a goal grounded in both economic and development aims, often little or no importance has been placed on maintaining connections with those in the population who do successfully complete this level of study. In other words, connections to and within the institution that were formed while studying typically end on graduation day with a handshake and a certificate and a loosely intended invitation to "keep in touch." While this scenario of losing ties with former students may seem relatively unimportant in the grand scheme of educating for development in these countries, scholarship is indicating that it has serious implications in light of the dramatically changing 21st-century world of work that these individuals will face. According to a recent Economist article ("Lifelong Learning," 2017), which highlights predictions for the outcome of current pressures of technology-driven changes to work, no country and few professions will be exempt from the effects of the global digital/AI transformation trajectory that faces us. And the only real solution to face the technological revolution already upon us is for individuals to become lifelong learners, or as major economic forecaster Deloitte (2016) reported, for structures to be in place for people to develop themselves every day (see also Bershin \& Zao-Sanders, 2019). In other words, learning cannot end with certification and inspiring music on graduation day; it must continue for a lifetime. The nurturing of and support for such lifelong learning trajectories must begin in HE institutions.

In a rapidly evolving country such as Chile, the economic advantages for institutions of a population seeking access to HE are well recognized and unprecedented (Sadlier \& Arancibia, 2015). In such a climate, the temptation for HE institutions is to simply provide an array of educational offerings and encourage its students just to achieve certification and move on. For institutions, the economic and pedagogical implications alone in achieving this mandate can be considerable. Still, many Chilean institutions, whether public or private, also acknowledge their wider societal responsibilities. The lofty aims of their policy statements typically reflect goals to promote 21st-century learning skills and lifelong learning in the profiles of their students. Yet, especially among younger HE institutions struggling to grow, such goals are oftentimes stuck at the level of rhetoric, as opposed to actually putting ideals into practice. On the other hand, if we examine the practices of leading HE institutions elsewhere particularly in the developed world, maintaining those connections and communities is a vital part of their day-to-day operations (Harrison et al., 1995). The efforts in these institutions are no doubt driven partly with an eye to increased endowments. Yet, they also reflect that the institutions clearly recognize the myriad advantages for society and the lifelong learning efforts of its population (Rubenson, 2006; UNESCO, 2015) when they foster connections with their graduating students over a lifetime.

Students in Chile also contribute to the mindset of "just do it and move on" in terms of their expectations for HE. Ideally, many who invest in higher learning, often thanks to the significant financial sacrifices of family, are able to access a return on their investment in the employment opportunities available after graduating. For those who have experienced high quality educational backgrounds, part of that return stems from the advantages of connections and relationships they form in their HE institution. Yet, the advantages of such community connections unfortunately often elude those who arrive at the HE level with less cultural capital (Bourdieu, 1998; De Graaf et al., 2000; Roseigno \& Ainsworth Darnell, 1999). In an evolving society such as Chile, many students in HE are first-generation attendees and with little experience of how to profit from the institutional opportunities offered at this level. These individuals risk remaining at the periphery in terms of what they need to prosper before, during, and after graduation. Indeed, many are often left struggling and to their own devices when it comes to development in their professional lives (Sadlier \& Arancibia, 2015). Indeed, Cummings (2015), who conducted an external study of recent student protests in Chile, found that a 
primary concern of current students was not judgments that their present training was of low quality but rather the low economic rewards once they graduate (Espinoza et al., 2016). We attribute the challenges many students in Chile face to the lack of a strong professional support network that other more advantaged students have learned how to foster over their years in formal education. In other words, graduating certificates are not sufficient for equitable success as a professional. The cultural divide thus is sustained, and lofty emancipatory ideals attached to further education remain unattainable.

\section{Actions Speak Louder Than Words}

As teacher-educators at the largest university in Chile, we have considered our role in reversing this trend and in supporting those who have left our classrooms. An important question is how to continue to offer guidance and opportunities for learning to former students. After all, as professionals ourselves, we are well aware, as Endedijk and colleagues (2014) pointed out, that "Becoming a professional means not only acquiring a specialized body of knowledge, it means also knowing how to keep developing oneself in the fast-changing knowledge economy" (p. 1). We have wondered what proactive steps we can take, as concerned educators, to (a) promote such self-development among our graduates and (b) foster in these former students a desire to continue to reach their potentials as citizens and professionals. In taking such deliberate action, we asked ourselves what influence there will be on (a) our alumni who are now out in the working world and (b) the obligation and value to our institution in supporting such initiatives.

In response to this reflection along with encouragement from program administrators, we established an initiative to rekindle connections with former students. This was accomplished through a digital newsletter to all former English-as-a-foreign-language (EFL) students who had completed the program since its inception in 2004. As full-time faculty members of the Department of English, we considered this initiative a means of addressing the goal of promoting lifelong learning. The initiative also took the shape of a qualitative ministudy, in which we collected data through a Likert scale online questionnaire, field notes, as well as individual interviews with several recipients of the newsletter. In all, three issues of the newsletter were distributed to 220 email addresses for EFL program graduates during the 2018 academic year.

In the remainder of the article, we describe details of the initiative and research process. In launching the inquiry, the aim was to understand and respond to the professional learning needs of alumni as they navigated the demands of their teaching careers. As Stanistreet (2019) pointed out, putting learners' needs first is critical. He emphasized that "effective ALE [adult learning and education] can be when it is offered flexibly and responsively, and when it is designed in a participatory way, with learners at the centre" (p. 857, emphasis added).

The focus was on a group of graduates from the EFL program who were employed in a variety of contexts across Chile. The following questions guided this action research study:

1. What is the nature of the professional circumstances that EFL program alumni experience once they leave the institution?

2. How do their circumstances influence the identities these individuals are mediating in their professional lives?

3. What influence if any can the fostering of an alumni community have on their development as professionals and relationship to the university?

In the next section, we begin by outlining the theory and literature that framed this inquiry. We then provide particulars about the methodological framework, including information about the institutional context, the participants, the design of the research process and the data analysis. At the end of the report, we discuss the 
findings and reflect on the implications of this action research study for our own institution and others who face similar challenges.

\section{Literature Review}

\section{Putting Theory to Practice}

HE faculty members are typically known for their lack of agreement; this discord is especially evident when it comes to pedagogy (Cavanaugh, 2019) and the institution's responsibilities to students in and after they have left the classrooms. And these steadfast epistemological and ontological differences are increasingly being highlighted as technology upsets the teaching profession's cultural, traditional, and steadfast principles (Carbonell et al., 2013). Yet, despite deep differences, most faculty agree on and share one principle-a passion for learning. Indeed, recent scholarship is revealing that passion and emotions are integral to the effectiveness of the learning process. In a large study of HE classroom students and their emotional response to learning situations, Pekrun et al. (2002) found that "there was virtually no major human emotion not reported by our participants" (p. 93; see also Pekrun \& Linnenbrink-Garcia, 2012). This research offers reminders that (a) emotions are ubiquitous in learning processes, and (b) for any activity with a goal to effectively promote knowledge construction, present or lifelong, the emotions of those involved must be considered in order for a passion for learning to be ignited. From this scholarship, we recognized that uncovering and acknowledging the emotions of our alumni during and once they have left the institution would be most helpful in understanding the nature of their cognitive, motivational, behavioral, cognitivebehavioral, and social-behavioral engagement towards lifelong learning and professional development (p. 259). In other words, efforts to promote connections for learning and development among alumni necessitated an awareness of their present emotions and conditions.

Increasing focus on scholarship in the last 2 decades on human emotion, that is, on learners themselves, their identities, and, importantly, the contexts of their learning, is based in sociocultural theory (Lantolf et al., 2015). Rooted in Vygtosky's (1978) educational theory, a broad range of groundbreaking studies from a sociocultural perspective have shown that intersubjective activity, that is, human interaction, is the precursor to knowledge development (Lantolf, 2000; Swain, 2001; Wertsch, 1991; Vocate, 1987). In our own work in learning research, particularly involving technology (Charbonneau-Gowdy, 2018; Charbonneau-Gowdy \& Chavez, 2019), we have extensively examined the quality of human interactions and relationships in learning contexts and what they indicate about individuals' willingness to invest in learning. Influenced by the seminal work of Norton (2013) in second language education and that of Fong et al. (2016) in technology-based learning, two fields in which our own research work is located, much of the focus has been on the theory of identity (see also Illeris, 2014, for a broader discussion of identity) and its connection to engagement in learning in a broad array of circumstances. Fong et al. (2016) defined identity as a site of struggle, changing across time and space and reproduced in social interaction. From this perspective, we understood at the outset of our action research initiative that alumni students in their own work realities mediate certain professional identities that may or may not be the imagined ones to which they aspire and that through interactions with others there was a potential for change. Yet, given the heavy demands in being a professional in Chile, particularly in education, there was interest in understanding more clearly how one can promote interest in forming these knowledge-building connections with current undergraduate pedagogy students, fellow graduates out in the teaching field and current university faculty.

Norton (Darvin \& Norton, 2015; Norton, 2016) has provided a framework for viewing complex levels of interest and engagement in learning. In her work, she conceptualized the term investment to explain the socially and historically constructed relationship between learners and their commitment to learning (Norton, 2015, p. 37). Individuals will invest in learning with the understanding that their involvement will lead to acquiring a wider range of symbolic and material resources that will in turn increase the value of their cultural 
capital and social power. Her explanation in part reveals how unequal opportunities of many of our Chilean students to quality early education experiences impacts their opportunities and openness to lifelong professional development. The construct also helps us to understand that in our attempt to promote lifelong learning among our alumni students, their involvement would hinge on demonstrating the kinds of professional resources and personal cultural benefits that were to be gained.

Recent studies that examine why individuals are drawn to lifelong learning focus mainly on formal HE courses and training rather than engagement of alumni in learning communities for professional development (Hovdhaugen \& Opheim, 2018). Those studies that focus solely on an individual's propensity towards seeking formal learning often rely on the concept of motivation which has historically been viewed as a static, or fixed, personality trait (Gardner \& Lambert, 1972). They use the construct of motivation to explain varied interests of certain individuals and not others to pursue ongoing professional learning development. Yet, there exists a paucity of research that is concerned with the sociocultural contextual issues that influence individuals to seek professional enhancing development activities, especially where the setting is an economically evolving country with a view to becoming increasingly globalized such as is Chile. Important to the present research study are those scholars who have unraveled the complex and dynamic relationships that exist in these kinds of contexts. Their work has shed light on how to promote lifelong professional learning through inspiring and maintaining connections. Gallo (2013), for example, working in the Irish HE context, highlighted the important and intrinsic link between an institution and its alumni, who are, after all, as Webb (1998) reminded us, the only permanent stakeholders of the institution.

Gallo's (2013) work is centered on the potential for institution-alumni links to have "a significant impact on an individual's life for life" (p. 1151). She has argued against the student as customer identity that characterizes much of the current discourse in HE, and especially evident to us in Chile. In her view, students turned alumni are key shareholders in the institution, "with a vested interest in its reputation and advancement" (p. 1151). Gallo has researched the kinds of opportunities available to alumni in a particular set of institutions. She examined how these opportunities can lead to changes in alumni relationships to the institution over time and by extension to valuable professional development opportunities. The empirical data collected from her case study indicated four stages of relationship building-affiliation, affinity, engagement, and support (Gallo, 2012). Alumni move through these stages depending on the nature of their personal life and work realities and the kinds of opportunities available to them from their institution. In the context of our study, these stages have helped inform us of the way our alumni see themselves, their identities as professionals, and the nature of their relationships to our institution. It is important to consider how to match the identities these alumni are constructing as professionals with the kinds of opportunities that the institution could offer, with a view to building a deeper and more productive community of learners made up of a diverse array of education stakeholders, that is, other EFL educators working in the system across Chile, undergraduate future EFL teachers, current university faculty, and program administrators.

In summary, there are compelling arguments in the scholarship for considering emotional factors as well as identity and investment issues involved in learning contexts. These ideas are rooted in sociocultural perspectives of learning and the various theories they have spawned. The theories embedded in this literature also highlight the importance of understanding contextual factors to explain the various levels of interest, or investment of alumni in furthering their professional learning beyond their undergraduate formal programs. There is a paucity of research that exists in the literature on lifelong learning that looks beyond engaging in HE formal professional development courses. Gallo's (2012) study of the four stages of relationship building explains that when opportunities are presented for building a community of learners, they will reach out to the institution and begin to recognize the cultural and professional capital available by renewing and furthering this relationship. 
With these theoretical views and foundational research in mind, we launched a newsletter to alumni in May 2018. The first issue included an inspirational message about the value of keeping in touch with the institution along with information about the current faculty members in the Department of English and their research interests and activities. In the early stages, the goal was to open the door to establishing a rapport with former students in the EFL and to encourage a positive response to our newsletters. We sought to spark within this group an interest in being involved in our initiative to build a community of alumni, faculty and future teachers enrolled in the Pedagogy Program. Additionally, the first issue also included links to upcoming professional development events in the form of conferences, workshops, and seminars available for EFL teachers across the nation.

Two subsequent issues sent out in July and November dealt with a variety of subjects raised by students in response to the initial newsletter. These topics included (a) strategies for teaching English in core subject areas, (b) tips on effective preparation for an interview for a teaching position, and (c) issues and advice around professional development and continuing education. With each of these three issues, our aim was to support and promote ongoing dialogue heretofore nonexistent or sporadic and isolated among alumni and members of the faculty. We also sought to provide a forum for an exchange of ideas that were pertinent to teachers at the front lines of education. At the same time, efforts reflected the value of social learning practices and lifelong learning that we uphold so strongly in our day-to-day teaching and which fuels our passion for learning.

Much of the information and resources provided in the newsletter were in reaction to alumni requests and comments. These included, for example, requests for professional development and continuing education information. The newsletter included resources of potential interest to alumni, including materials such as those located in the Learning Policy Institute (Darling-Hammond et al., 2017), the Organization for Economic Cooperation and Development (Organization for Economic Co-Operation and Development, 2009) documents (Chile being its newest member), and the Peterson's (2018) articles, a leading publication on graduate studies. Our prime aim was to avoid being solely an information source but rather to encourage professionally enriching dialogue among these alumni. A careful selection of resources including pertinent academic scholarship and the implication of faculty and their extensive experiences in the columns of the newsletter helped ensure lively discussion among interested alumni. Issue 2, for example, included a publication by one of our faculty members on the importance of technological innovations to foster autonomous learning.

Articles in the newsletter were not solely limited to those by faculty nor to scholarship, or to public domain information. In the spirit of creating a forum for dialogue, the newsletter also included columns written by individual alumni with experience in an area that matched the topics of particular issues raised by the readership. These included for example testimonies of experiences and knowledge gained from attendance at a recent International Association for the Teaching of English as a Foreign Language and insights into the value of these events for changing mindsets and professional development. Together this information and experience sharing were intended to build and foster the kinds of conversations that are considered the basis of learning - that is, new thinking-and development. In the remainder of the report, the methodological details of the study are provided as well as discussions of the analysis and findings.

\section{Methodology}

This study is a miniqualitative action research inquiry. The researchers have significant experience in using this approach and recognized its power to address the research questions. Action research is well suited to investigate complex human activity and uncover participants' voices (Creswell, 2007; Denizen \& Lincoln, 2005) - of particular importance in light of the research aims. Data included the combination of (a) field notes 
from our experience, anecdotal evidence and research of our more than 20 collective years teaching and researching the program (Charbonneau-Gowdy, 2018); (b) results of a Likert-based questionnaire, which provided background information and some general feedback from participants; and (c) responses from indepth individual interviews from self-selected participants. Interview questions (see Appendix B) were sent to self-selected participants, and their responses were returned in audio recording format. The decision was made to conduct interviews in this way due to logistical challenges in scheduling face-to-face encounters with individuals located across the country. It is important to note that ethical guidelines established by our institution to protect the rights and privacy of our participants were strictly adhered to throughout the study process. Along with this adherence, an ethics of "caring" (Christians, 2000) characterized the research process throughout. Interview participants signed written consent forms, were assured that the results of the study would be used solely for educational purposes and pseudonyms were employed in all cases to protect their privacy. The lead author is a professionally trained international researcher with over 10 years of scientific research background.

\section{Context}

The research was conducted at a Chilean private, for-profit university belonging to an international network of HE institutions worldwide. The university was founded in 1988 during the military dictatorship in Chile. This institute along with other still expanding numbers of private HE institutions were established as a result of the Chilean population's increasing demands for HE that could not be met by the existing eight state-subsidized universities in the country. These latter eight institutions have traditionally attracted society's elite, mostly private-school-educated students with the highest HE entrance exam scores in the country. From its inception, our own private university has had the goal of becoming a pluralistic, inclusive HE institution to promote social progress and mobility for students in all social sectors. These goals might explain why the university eventually became the largest (in terms of enrolment) in the country with thirteen campuses in three major cities, including Chile's capital, Santiago. Students come from all areas of the country to attend the university and subsequently often return to their hometowns for employment, with little ties to the institution once they leave. The university's focus on research in life sciences and other disciplines has resulted in its status as the first private university in Chile to be granted accreditation in research. Also, it is distinguished for the number of degree and professional certificates it has been able to grant since its founding, including teaching certifications to the over 300 EFL teachers who have graduated from the English Pedagogy Program.

The project was launched in an effort to connect with approximately 200 of the 300 alumni for whom we had current contact information, particularly those who were in EFL teaching positions. At the same time, we were seeking to conform to national accreditation directives and a newly established government law that required the program to establish formal channels of communication with their alumni. The purpose of establishing these open lines of communication links with alumni was to obtain feedback about their needs and changing work cultures in the field of education nationally. The English Gazette, the name given to the newly established digital publication, formed part of this response.

\section{Participants}

The participants of our study were the graduates of our EFL program who received the newsletter. As pointed out, the university attracts a broad range of students from a variety of socioeconomic backgrounds. Many in the program are on government scholarships and while others are forced to supplement family financial support with income from part-time work. Most are the first in their families to be granted university degrees. These profiles then would be the background profiles of the majority of participants of the study, that is, recipients of the newsletter. Our newsletter was sent out to all 300 alumni, and it was presumed that those who replied were actively teaching in a variety of regions in Chile and were employed in the various levels of the education system-an assumption made based on our ongoing contact with some of these alumni as well 
as information gathered from social network connections maintained by the authors with many former students. The survey/questionnaire itself was sent to 181 individuals, the number for whom accurate current contact information was available; 41 of those contacted responded. Interviews were conducted with a group of eight self-selected alumni who had also been actively engaged in the community of learners that evolved as a result of the newsletter.

\section{Research Design}

Data collection began with the launch of the first newsletter in May 2018 and ended after the third issue was published in November of the same year. The purpose of the newsletter was to offer a community forum for exchanging information about professional development opportunities, advice for novice and seasoned professionals, information about events at the university, and endeavours undertaken by other alumni. By establishing a community, the newsletter also offered valuable insight into the professional realities of our alumni and updates needed in our program that would have better prepared them for their professional work. Table 1 provides an overview of the design of the ministudy. The main topics highlighted in each newsletter are listed as well as information about the data collection process over the first year of the newsletter's publication.

Table 1. Phases of the Study

\begin{tabular}{|c|c|c|c|}
\hline Phase & Activity & Type of data & Example \\
\hline \multirow[t]{2}{*}{$\begin{array}{l}\text { Phase } 1 \text { (May to } \\
\text { June 2018) }\end{array}$} & \multirow{2}{*}{$\begin{array}{c}\text { Distribution of Newsletter } 1 \text { on } \\
\text { the topics (a) faculty research } \\
\text { and activities and (b) invitation } \\
\text { to targeted alumni for } \\
\text { community sharing and } \\
\text { comments }\end{array}$} & Emails & $\begin{array}{l}\text { Written reflections, responses, and } \\
\text { suggestions from former students } \\
\text { reacting to the newsletter }\end{array}$ \\
\hline & & Field notes & $\begin{array}{l}\text { Reactions from faculty and } \\
\text { administration to the newsletter }\end{array}$ \\
\hline \multirow[t]{2}{*}{$\begin{array}{l}\text { Phase } 2 \text { (July to } \\
\text { October 2018) }\end{array}$} & \multirow{2}{*}{$\begin{array}{l}\text { Distribution of Newsletter } 2 \text { on } \\
\text { the topics (a) EFL teaching in } \\
\text { core subject areas, (b) } \\
\text { preparing for an EFL job } \\
\text { interview, and (c) EFL resource } \\
\text { and research materials } \\
\text { information }\end{array}$} & Emails & $\begin{array}{l}\text { Written reflections, responses, and } \\
\text { suggestions from former students } \\
\text { reacting to the newsletter }\end{array}$ \\
\hline & & Field notes & $\begin{array}{l}\text { Reaction of faculty and administration } \\
\text { to the newsletter }\end{array}$ \\
\hline \multirow[t]{4}{*}{$\begin{array}{l}\text { Phase } 3 \\
\text { (November to } \\
\text { December 2018) }\end{array}$} & \multirow{4}{*}{$\begin{array}{l}\text { Distribution of Newsletter } 2 \text { on } \\
\text { the topics (a) information } \\
\text { regarding PD and CE, (b) } \\
\text { shared stories from alumni of } \\
\text { their experiences with PD and } \\
\text { CE, and (c) resource material } \\
\text { on conducting research }\end{array}$} & Emails & $\begin{array}{l}\text { Written reflections, responses, and } \\
\text { suggestions from former students } \\
\text { reacting to the newsletter }\end{array}$ \\
\hline & & Field notes & $\begin{array}{l}\text { Reactions from faculty and } \\
\text { administration to the newsletter }\end{array}$ \\
\hline & & $\begin{array}{l}\text { Questionnaire } \\
\text { results }\end{array}$ & Responses from 60 alumni \\
\hline & & Interview notes & $\begin{array}{c}\text { Written transcripts of responses to } \\
\text { interview questions }\end{array}$ \\
\hline
\end{tabular}

Note. $\mathrm{EFL}=$ English as a foreign language $\mathrm{PD}=$ professional development $\mathrm{CE}=$ continuing education .

\section{Data Analysis}

Datasets consisted of (a) collective contributions from the various sources that formed the content of the newsletters, (b) field notes including the researchers' reflective memos and alumni emails, (c) responses from the follow-up questionnaire distributed to alumni readership, and (d) interview transcriptions. 
One of the important sources of data in the inquiry were the responses to an online questionnaire distributed to alumni readers after the third publication (see Appendix A). The goal of this instrument was to obtain feedback on the newsletter and information related to professional development pursuits and aspirations from the alumni readership in an effort to tailor content in subsequent newsletter issues. The responses to this questionnaire also acted as the basis of the questions and topics pursued in the individual interviews (Appendix B). The data from the various sources then were closely connected, thus serving a crucial means to triangulate the findings. For example, by cross-referencing data from the questionnaire with that of the interviews and vice versa, and with data that emerged from the field notes, the findings were able to be verified and validated. This process of validating added weight to the reliability of the findings and reduced the possibility of skewing the results through researcher bias.

Drawing from the rich variety of qualitative analysis possibilities, the datasets were analyzed from a combined inductive-deductive perspective. After establishing a conceptual framework, the data was inspected through a series of iterative steps. The first step consisted of inspecting the data sets, in a quantitative sense, to determine the data available that could inform the research questions. Then through multiple readings and consideration of the datasets, the data was significantly condensed and coded, initially in an open-ended analysis process and then for determining those data that related to the literature review and theoretical framework. From the code list, overarching themes or categories were determined and lastly a final conceptual framework with the supporting data sets was established and examined to ensure that the research story would be corroborated by the findings (Miles et al., 2014; Kalpokaite \& Radivojevic, 2019). It is important to point out that the emic perspective brought by the authors to the analysis process along with the open channel of communication they conducted with various members of the readership, which allowed for cross-referencing, added further to the reliability and validity of the findings.

\section{Results}

The initial launch of the alumni newsletter was met with mixed reaction in the English department. Guarded excitement among faculty was combined with a certain reservation and indeed skepticism about the kind of reaction the newsletter would generate among students. It is commonly believed among faculty that Chileans, particularly students, have a cultural reticence towards sharing views and opinions, not to mention seizing opportunities for learning without compensation in some form attached. For example, it is not unusual for teachers to report that students regularly inquire about grades given when asked to participate in in-class group activities and be reticent to do so, if there are none attached. It is well established within the department that sponsored workshops or lectures offered by visiting scholars must be scheduled during class time when students are compensated for their attendance, otherwise they would not attend. Work assigned to be done outside classroom hours is often not accomplished unless it has a considerable grade attached. The fact that there was only total of 41 questionnaire respondents from a potential of 181 surveyed and only eight who agreed to be interviewed, could be an indication of this culture peculiarity. On the other hand, we have no knowledge of how many alumni actually read the newsletter-numbers could be much greater than those who responded. Yet, the data that emerged from those who did engage and respond, combined with that from the other data sets, provided important insight with regard to our research questions. Two salient themes emerged from the data: (a) the enthusiasm for professional development and for which we have coined the phrase "Give me a good rod and you set me up for a lifetime" and (b) the value of socially-based community learning for professional development-"See that I have much to learn and even more to share." In both of these themes, the role of the university is inextricably interwoven.

\section{"Give Me a Good Rod and You Set Me up for a Lifetime"}

Learning and development are the result of being provided with the "right" tools and circumstances. To paraphrase Confucius, “Give a man a fish, and you'll feed him for a day. Teach a man to fish, and you've fed 
him for a lifetime.” These words reflect the kinds of supportive conditions, that is, the right tools that ultimately influence individuals in adopting the kinds of professional identities that lead to lifelong learners. This theme permeated the data that emerged from all four data sets (see Table 1). Many alumni expressed in a variety of ways that the myriad challenges of their teaching realities left them feeling underskilled and unprepared-not the kinds of identities that lead to feelings of effectiveness or being empowered in one's role as teacher. Some spoke of working with at-risk young people in vulnerable schools and the expectations on them beyond teaching to act as "psychologists, therapists and educational experts" (Paco, interview in November 2018) with little or no experience. Others commented on their feelings of unpreparedness when asked to assume leadership roles in privileged bilingual schools and with gifted children. These sentiments were confirmed by other data sets. For example, responses on the questionnaire indicated that $92.7 \%$ of respondents expressed a need to acquire new and more effective tools to face their professional challenges (see Appendix C). Importantly, and not surprisingly, only 53.7\% considered professional development days or seminar events as effective tools for meeting their professional development needs and for supporting their mediating more empowered and knowledgeable identities as teachers. As Franco shared,

[I] attended some workshops given by an institution, but I have not had a good experience ... the contents are very shallow and sometimes too, like, marketing ... They're trying to sell products rather than teaching something that can contribute to what teachers are doing ... these workshops have not contributed to my practice development at all ... or professional development. And, apart, they're too expensive, so it becomes a waste of time and money.

From this testimony, we understand the limited value that these kinds of institutionally planned professional development events had for this participant. The self-serving and market-driven intentions of the private organizers contracted by his institution seriously underestimated the professional needs of this teacher who was looking for effective tools to support his work and his professional identity. His skepticism about these types of one-off events was reflected generally in data that emerged in triangulating the other data sets. For example, from the comments made in response to the newsletter, it was evident that according to these alumni the theory and information that is the backbone of typical formal learning courses, workshops and seminars do not in themselves provide the optimal tools needed for professional and personal development. Their requests for ongoing experiential advice revealed their need for alternative, practical, and sustained ways of learning.

Despite their general reservation about one-off occasions for professional development, alumni responded favorably to our newsletters' hands-on practical subject matter that was the basis of each issue. Of those who were surveyed, $90 \%$ indicated that the subject matter was relevant. One graduate we interviewed poignantly remarked, "This sort of content is your safe place, your comfort zone" (Bárbara). We understand from this comment that for this particular alumnus, the various topics that were raised for discussion in the newsletters succeeded in providing the much needed support this individual sought in face of what many of our former students have voiced to us-the sometimes insurmountable challenges that teachers face in their practices which leave many feeling lacking in terms of their professional identities. Others called for even more practical topics to be included in the newsletters. For example, Paco expressed, "More focus on what teachers do." This suggestion, which highlights the power of connecting individuals to share their practical knowledge, was repeated often in the testimonies of the participants.

From a sociocultural perspective, we understood that for many of the participants, the alumni newsletter, unlike one-off events, provided an ongoing community forum that acted as a safe place for discussing the demands of their day-to-day practices and possible professionally developing solutions that would lead to change and lifelong learning. 


\section{"See That I Have Much to Learn and Even More to Give"}

The second theme that emerged was the value that many alumni see in learning in community with others. Bárbara mentioned delight in unexpectedly being contacted and sent a newsletter from the university:

[I] was really surprised because I was not expecting that at all! What I expected when I left university on the last day of my studies ... um ... I-I thought I wouldn't be contacted by any of you any time soon.

Another alumnus, Juan Pablo, spoke of the importance of the newsletter as an initiative "generated by the entire community for the entire community." This theme was repeated and confirmed in data that emerged from the questionnaire: $80.5 \%$ of respondents indicated that they felt as a member of our community when reading the newsletter. Excitement and favourable responses on the part of some to being welcomed into a community of alumni supported by the institution were in sharp contrast with the kinds of stereotypical reactions faculty had expected. Importantly, data from all four data sets confirmed that the newsletter was seen more than just a source of information but rather a space for influential community building with other alumni, faculty, and the institution. For example, importantly one participant commented on the questionnaire with a suggestion that former students share their expertise in the field with current preservice teachers in the program.

Data from interviews also revealed the advantages felt by some participants for learning from others in community, in particular about their graduate studies experiences that appeared as a column in the newsletter. Franco remarked, "[Learning about their experiences is] more encouraging for me to develop." In our analysis, these words suggest to us that the understanding gained and underlying fears addressed by reading about a fellow alumnus' own experiences in graduate school acted as an important incentive to this individual to return to formal studies. Bárbara expressed a similar reaction to the article: "I want to study a Master's on Linguistics and most likely ... at Universidad de ..., so, [reading about the experiences of others] it's like tasting what it should be like, in a way."

And then Bárbara continued her remarks by explaining that hearing reading about the further academic studies of another alumnus in the newsletter is like "tasting like it should be like," in other words, living the experience. This testimony demonstrates the power and influence that witnessing the experiences of others in a community can have to similarly invest in lifelong learning activities such as pursuing further studies. As Franco expressed it, "it's a good way to ... to have ... or increase my desire to develop professionally."

Regardless of the form that the community takes, when individuals connect to mediate expertise and knowledge with others, the possibilities for influencing each other's development are unlimited. The data from the various data sets confirmed the potential of the newsletter to provide a forum for such community building. In the following excerpt, Juan Pablo expressed this democratic potential:

... I believe this newspaper is an effective communication tool that connects students, faculty and local community by allowing us to interact in a horizontal manner that strengthens our bonds and also fosters trust ... as members of a community.

Juan Pablo was attesting to the fact that within the community of alumni made possible with the newsletter, there is a blurring of historical lines between faculty and student, between the graduate and undergraduate, across the socioeconomic boundaries that are usually so clearly defined in Chilean society, between experienced and less experienced and the lines of gender that are deeply pervasive in this culture. In doing so, the opportunity provides a space for building trust and professional bonds-the ideal spaces, according to sociocultural theory to promote learning and in this case professional as well as personal development. 
The value of the community of learners that was created as a result of the newsletter can be viewed through the lens of Gallo's (2012) four stages of relationship building. Over the course of the study, there was a progressive change in the extent and quality of involvement on the part of some alumni in the community and in the degree to which they exploited the development opportunities that the newsletter was supporting. In the section below, we use this conceptual framework for our data analysis of the kinds of professional development that took place over the first year of the project.

\section{Affiliation}

Getting the newsletter over the last months has been a very nice experience because it helps you feel closer to the teachers at university and the classmates ... You realize that you can talk to them whenever you need some help. (Francisca)

In this excerpt, Francisca expressed the feelings of attachment she is beginning to experience toward others in the community from the institution and teachers like herself. She attested to the positive nature of this emerging relationship and the advantages she foresees in continuing to invest in it and the community.

\section{Affinity}

[It] has been useful to get some tips about different issues that we face, such as job interviews, or experiences, such as teaching other subjects by the means of English or ... uh . . . or just simply knowing where our former classmates are working, which is very interesting because I have seen that most of contexts are very similar. (Franco)

This testimony reveals the advantages that Franco recognized in taking a further step in identifying with others in the community. At this stage, he bore witness to the fact that he had much to learn as well as to gain from sharing similar professional needs and experiences with others.

\section{Engagement}

Four attended the IATEFL [International Association for the Teaching of English as a Foreign Language]-Chile conference in July of 2018 on a scholarship provided by the English Teaching Program at our university, and the fifth student attended the Chilean Ministry of Education's Winter Retreat.... All five provided written testimonials on those experiences, how they changed their own perspectives on professional development, and shared advice with current and former students on the importance of taking part in these initiatives and their significance for their continuing education.

In this excerpt from our February 2019 field notes, lead editor of The English Gazette and coresearcher reported on examples of some members who have joined the newsletter community and who have taken a further step in actively engaging in sharing their knowledge, experiences and informed advice about their own professional development activities with other members.

\section{Support}

Maybe the university or the program could arrange some talks or ... simposios [sic], or ... different instances in which we can exchange maybe our experience or previous studies that we have done... good option would be sharing ideas with others, but in a way that we can actually show what we're doing. So, yeah ... I mean sharing good practices or successful activities, so I think that a sort of meet-and-share opportunity would be a good idea or to have something like a fair of ideas in which . . . uh ... in which teachers would share what has been useful and has worked in their lessons ... (Franco)

With these words, Franco expressed his desire to move beyond assuming a receiving role in the new community formed by the outreach of the newsletter. He envisaged finding a way to give back. He suggested that he and fellow alumni-who were considered to be experienced teachers-expended considerable time and 
effort to meet with future teachers in the program and to share their practical support with what lies ahead in their future careers. He expressed a genuine and altruistic desire for his group to act as experienced guides in preparing the undergraduates in the program for the realities they will face in the classroom. His words reflected the true vision of an effective learning community.

\section{Discussion}

Returning to our theoretical framework provides support for the two themes that emerged from the data analysis. The first theme reflects the general call from alumni in the context of the inquiry for more practical tools-through insight and stories recounted by other alumni about the challenges and realities they face in their teaching practices. Our analysis indicated that these accounts, according to those who participated in the study, served as a way to inform and develop one another. We understood that at the basis of this call were the various degrees of vulnerability that many alumni were sensing in their professional lives as teachers. Drawing from theory suggests that this acknowledgment of insecurity is an important first step in professional development. Acknowledging the precariousness of one's professional emotional state leads often to action according to Pekrun and Linnenbrink-Garcia (2012). The authors have shown that where individuals feel vulnerable in their profession, they seek help and security in what they do in their practices to be and importantly to feel effective. The confidence and security gained from opportunities to mediate with others like themselves about their professional teaching practices in the context of the newsletter provided what one alumnus referred to as a "safe place" from where these alumni teachers could reflect and decide on how to face the myriad complexities of their professional realities. The support gained is indicative of effective communities of learning (Farnsworth et al., 2016; Lave \& Wenger, 1991) and reflects the value of social learning for mediating new knowledge and professional development.

With regard to the second theme, we have traced above the trajectories of various alumni and aligned these changes with Gallo's (2012) four stages of relationship building that are made possible in communities-from a stage of greater affiliation with the university, to feelings of affinity and then acts of engagement and active support of the institution. These trajectories can also be viewed through the lens of identity theory and investment (Darvin \& Norton, 2015). The analysis of the various data sets confirmed that, with each new issue, many of the engaged readership members progressed from demonstrating increased feelings of belonging, then to actively engaging in sharing with other EFL educators in the field like themselves and finally to an altruistic and self-directed desire to move to the periphery of the community to offer active support to those less experienced members-future teachers still studying at the undergraduate level. The increased levels of engagement on the part of some alumni with the institution and the community of learners it represents, and an openness to actively invest in professional development activities demonstrates the symbolic value they see in this relationship building in terms of their professional careers. The cultural capital that many of these individuals may have not had access to while undergraduates is on offer once again in the context of the newsletter and the community relationships it fosters. Our analysis clearly demonstrates that at this stage, perhaps unlike during their undergraduate years, some of the alumni finally realize the advantages of involving themselves in this relationship building and the social power that could be gained through the professional development that doing so entails (Sadlier \& Arancibia, 2015).

Although the evidence we report is positive, it is not meant to suggest that this trajectory was universal. Clearly there were many other alumni who did not show such signs. Yet, based on the strong evidence we uncovered, the community-building supported by the newsletter suggests at least lifelong learning implications for those who did participate.

We believe the same quotes from our study offer compelling evidence of the valuable gains to be realized by our university-driven action to promote development and learning well beyond the classroom and course 
offerings. The support on the part of the university, alumni and faculty for the sustained need for the newsletter is another. As we complete this report, the sixth issue of The English Gazette had been published and distributed-a further testament to the sustainability and relevance of the publication and what it represents.

One of the major takeaways from these findings is that they provide a clearer picture of what can be done in this context as well as others for institutions to attract a greater number of alumni to invest in professional learning communities such as the one we report on here. Armed with our findings and informed by Gallo's model, the implications are that institutions need to begin to foster more actively a strong community of learning while students are attending the institution and then continue to build on this connection once they have left. These communities must be "safe" places where students can begin to see the value to their identities as learners and future teachers in the investment that comes with belonging, connecting, engaging and giving back to a community of learning that includes a broad group of stakeholders. With the current array of social networking tools available, these communities can easily move on to more convenient online spaces. Undoubtedly, one of the key limitations in our initiative were the drawbacks and challenges resulting in our decision to use pdf newsletters and emails to connect with participants in the community. This decision could account for a further limitation of the present study-the significant yet rather limited number of alumni we succeeded in reaching. One way to overcome such limitations in future iterations would clearly be to take advantage of the broad array of powerful social media tools currently available as a more efficient and effective way to build connections and interact more actively within an alumni community. Indeed, the options are so much greater for those who wish to replicate the study.

\section{Conclusion}

Teaching is a lonely profession in many ways, yet essential to society's development. After 4 years of pedagogical formation, we set loose teachers, like many other professionals certified in HE institutions, for professional lifetimes in which they are left to fend for themselves. Providing a forum for community building among teaching alumni strongly suggests a way forward for those faced with the realities that their early years of training have left them unprepared, at least in practice. As technological advances are infiltrating all sectors of society, we are experiencing changes in these spaces and in ourselves as human beings, like never before. Comfort and respite from these new challenges as well as advancement can only come from the combination of individuals and communities working together to develop and adapt to the changes we are living. We agree with Sadlier and Arancibia (2015) who observed, "Problems of development become problems of pedagogy" (p. 1058). Their observation, although directed at Chile, provide insight to solutions for any country or indeed institution whose education system could better serve those who are entrusted to its care.

For ongoing professional development to be promoted both at the institutional and country level, the report of our initiative offers one example of a way forward. Our extensive data supports the fact that this relatively small initiative had a significant impact on a group of the alumni from our institution, both in terms of providing practical tools and resources for professional development as well as an opportunity for these professionals to belong to a strong and supportive learning community. There were many in the community we did not reach. Yet, added to the advantages available to those we did, we witnessed how some of these former students moved from being affiliates to supporters of their institution-a clear sign of a win-win scenario for both. Juan Pablo's insightful remark illustrates the advantages he saw in our insitutional initiative in the following insightful reflection:

[The newsletter articles] ... helped me to know myself better. To learn a new knowledge would fall too short as a definition of professional development. For me, professional development means to discover the world that surrounds me and the world that is inside me. Through professional development, we can find a purpose in this world and, consequently, be absolutely satisfied with the life we are all given. 
In the present complex and rapidly changing world, or what Zigmnunt Bauman (2012) referred to as "liquid modernity," finding our purpose and building on that purpose no matter how that purpose evolves over one's lifetime will undoubtedly require extraordinary conditions and transformations in our professional identities. We believe social interactive opportunities for lifelong learning such as those we propose here, but offered on a much broader scale and by many more institutions, would be a viable solution for promoting personal, economic, and societal growth.

\section{References}

Bauman, Z. (2012). Liquid modernity. Polity Press.

Bershin, J., \& Zao-Sanders, M. (2019, February). Making learning a part of everyday work. Harvard Business Review. https://hbr.org/2019/o2/making-learning-a-part-of-everyday-work

Bourdieu, P. (1998). Acts of resistance: Against the new myths of our time. Polity Press.

Carbonell, K., Dailey-Hebert, A., \& Gijselaers, W. (2013). Unleashing the creative potential of faculty to create blended learning. Internet and Higher Education, 18, 29-37.

Cavanaugh, S. R. (2019, February 8). Address to faculty at Claremont Colleges'Center for Teaching and Learning. Pumona College.

Charbonneau-Gowdy, P. (2018). Beyond stalemate: Seeking solutions to challenges in online and blended learning programs. The Electronic Journal of e-Learning, 16, 56-66.

Charbonneau-Gowdy, P., \& Chavez, J. (2019). 3-M model for uncovering the impact of multi-level identity issues on learners' social interactive engagement online. The Electronic Journal of e-Learning, 17(2), 131-143.

Christians, C. G. (2000). Ethics and politics in qualitative research. In N. K. Denzen \& Y. S. Lincoln (Eds.), Handbook of qualitative research (pp. 133-155). Sage.

Creswell, J. W. (2007). Qualitative inquiry and research design: Choosing among five traditions (2nd ed.). Sage.

Cummings, P. (2015). Democracy and student discontent: Chilean student protest in the Post Pinochet era. Journal of Politics in Latin America, 7(3), 49-84.

Darling-Hammond, L., Hyler, M. E., \& Gardner, M. (2017, June 5). Effective teacher professional development. https://learningpolicyinstitute.org/product/effective-teacher-professionaldevelopment-report

Darvin, R., \& Norton, B. (2015). Identity and a model of investment in applied linguistics. Annual Review of Applied Linguistics, 35, 36-56.

De Graaf, N., De Graaf, P., \& Kraackamp, G. (2000). Parental cultural capital and educational attainment in the Netherlands: A refinement of the cultural capital perspective. Sociology of Education, 73(2), 92111.

Deloitte. (2016). Global human capital trends report. https://www2.deloitte.com/insights/us/en/focus/human-capital-trends/2016.htmlDenizen, N., \& Lincoln, Y. S. (Eds.). (2005). Handbook of qualitative research. Sage.

Endedijk, M., Vermunt, J., Meijer, P., \& Brekelmans, M. (2014). Students' development in self-regulated learning in postgraduate professional education: A longitudinal study. Studies in Higher Education, 39(7), 1116-1138. https://doi.org/10.1080/03075079.2013.777402 
Espinoza, O., González, L. E., \& Mcginn, N. (2016). The student movement in Chile and the neo-liberal agenda in crisis. In S. Fadaee (ed.), Understanding southern social movements (pp. 168-185). Routledge.

Farnsworth, V., Kleanthous, I., \& Wenger-Trayner, E. (2016). Communities of practice as a social theory of learning: A conversation with Etienne Wenger. British Journal of Educational Studies, 64(2), 139160. https://doi.org/10.1080/00071005.2015.1133799

Fong, C., Lin, S., \& Engle, R. (2016). Positioning identity in computer-mediated discourse among ESOL learners. Language Learning \& Technology, 2O(3), 142-158. http://lt.msu.edu/issues/october2016/fonglinengle.pdf

Gallo, M. (2012). Beyond philanthropy: Recognizing the value of alumni to benefit higher education institutions. Tertiary Education and Management, 18(1), 41-55.

Gallo, M. (2013). Higher education over a lifespan: A gown to grave assessment of a lifelong relationship between universities and their graduates. Studies in Higher Education, 38(8), 1150-1161.

Gardner, R., \& Lambert, W. (1972). Attitudes and motivation in second-language learning. Newbury House.

Harrison, W., Mitchell, S., \& Peterson, S. (1995). Alumni donations and colleges' development expenditures: Does spending matter? American Journal of Economics and Sociology, 54(4), 397-412.

Hovdhaugen, E., \& Opheim, V. (2018). Participation in adult education and training in countries with low participation rates: Demands and barriers. International Journal of Lifelong Education, 37(5), 560577 .

Illeris, K. (2014). Transformative learning and identity. Journal of Transformative Education, 12(2), 148163.

Johnson, K. E. (2013). Innovation through teacher education programs. In K. Hyland \& L. Wong (Eds), Innovation and change in English language education (pp. 75-89). Routledge.

Kalpokaite, N., \& Radivojevic, I. (2019). Demystifying qualitative data analysis for novice qualitative researchers. The Qualitative Report, 24(13), 44-57.

Lantolf, J. P. (2000). Sociocultural theory and second language learning. Oxford University Press.

Lantolf, J. P., Thorne, S. L., \& Poehner, M. E. (2015). Sociocultural theory and second language development. In B. VanPatten \& J. Williams (Eds.). Theories in second language acquisition: An introduction (pp. 207-226). Routledge.

Lave, J., \& Wenger, E. (1991). Situated learning: Legitimated peripheral participation. Cambridge University Press.

Lifelong learning is becoming an economic imperative. (2017, January 12). The Economist. https://www.economist.com/special-report/2017/01/12/lifelong-learning-is-becoming-an-economicimperative

Miles, M. B., Huberman, A. M., \& Saldaña, J. (2014). Qualitative data analysis: A methods sourcebook (3rd ed.). Sage.

Norton, B. (2013). Identity and language learning: Extending the conversation (2nd ed.). Multilingual Matters.

Norton, B. (2016). Identity and language learning: Back to the future, TESOL Quarterly, 5O(2), 475-479.

Organization for Economic Co-Operation and Development. (2009). Creating effective teaching and learning environments: First results from TALIS. http://www.oecd.org/education/school/43023606.pdf 
Pekrun, R., Goetz, T., Titz, W., \& Perry, R. (2002). Academic emotions in students' self-regulated learning and achievement: A program of qualitative and quantitative research. Educational Psychologist, 37(2), 91-105.

Pekrun, R., \& Linnenbrink-Garcia. L. (2012). Academic emotions and student engagement. In S. Christenson, A. Reschly, \& C. Wiley (Eds.). Handbook of research on student engagement (pp 259-282). Springer.

Peterson's. (2018, January 3). A guide for potential grad students: Should you go to graduate school? https://www.petersons.com/blog/a-guide-for-potential-grad-students-should-you-go-to-graduateschool/

Roseigno, V., \& Ainsworth Darnell, J. (1999). Race, cultural capital, and educational resources: Persistent inequalities and achievement returns. Sociology of Education, 72(3), 158-178.

Rubenson, K. (2006). The Nordic model of lifelong learning. Compare: A Journal of Comparative and International Education, 36(3), 327-341.

Sadlier, S. S., \& Arancibia, M. C. (2015). Toward a society where everyone is always studying: Access at an elite Chilean research university. International Journal of Qualitative Studies in Education, 28(9), 10491064 .

Stanistreet, P. (2019). Putting the learner at the centre: Quality in adult learning and education. International Review of Education, 65, 853-857.

Swain, M. (2001). Integrating language and content teaching through collaborative tasks. The Canadian Modern Language Review, 58(1), 44-63.

UNESCO. (2015). Recommendation on adult learning and education. https://unesdoc.unesco.org/ark:/48223/pfooo0245179

Vocate, D. (1987). The theory of A.R. Luria. Lawrence Erlbaun Associates.

Vygotsky, L. S. (1978). Mind in society: The development of higher psychological processes. Harvard University Press.

Webb, C. H. (1998). The alumni movement: A history of success. In W. W. Tromble (Ed.), Excellence in advancement: Applications for higher education and nonprofit organizations (pp. 213-228). Aspen Publishers.

Wertsch, J. (1991). Voices of the mind: A sociocultural approach to mediated action. Harvard University Press.

[Appendices follow] 


\section{Appendix A}

\section{Pedagogy Program Alumni Research: Survey Questionnaire}

\section{Section 1}

\section{About the newsletter}

Please check the appropriate option to answer each of the following questions regarding our newsletter The English Gazette.

1. Have you read all the previous issues of the newsletter?

$\square$ No

$\square$ Yes

2. Have you found the information to be relevant for your own development?

$\square$ No

$\square$ Yes

3. Have you found the newsletter to be useful for your own professional activity?
$\square$ No
Yes

4. Do you often read information associated with your professional activity?
$\square$ No
$\square$ Yes

5. While reading the newsletter do you feel as a member of our community?
$\square$ No
$\square$ Yes 


\section{Section 2}

\section{About your professional development}

Please check the appropriate option to answer each of the following questions regarding your interest in furthering your professional development.

1. Do you have time for any professional development?
$\square \quad$ No
$\square$ Yes

2. Have you in the past or are you currently contemplating pursuing any professional development activities?
$\square \quad$ No
$\square$ Yes

3. Have you in the past or are you currently contemplating pursuing professional development in the form of graduate studies?
$\square \quad$ No
$\square$ Yes

4. Attending professional development events, such as conferences, seminars, workshops, and other activities, has a direct impact on my performance as a teacher.

$\square$ Strongly agree

$\square$ Agree

$\square$ Neither agree nor disagree

$\square$ Disagree

$\square$ Strongly disagree

5. Pursuing graduate studies is a fundamental step to take in order to grow as a professional.

$\square$ Strongly agree

\section{Agree}

Neither agree nor disagree

Disagree

$\square$ Strongly disagree 


\section{Appendix B}

\section{Interview Questions}

Following are topics we would like you to address with you in more detail than you were able to do in completing the questionnaire. Please record your answers and forward the audio file to us at your earliest convenience. We appreciate your support of our research initiative.

1. Can you tell us what you have been doing since you graduated from the Pedagogy Program at UNAB?

2. Tell us a little about your reaction to receiving our newsletter over the last several months. In what ways could it offer you more in terms of your desire to develop professionally?

3. Talk to us about some of the activities you have been involved in for professional development since you graduated? Explain how they have they been useful or tell us in what ways not?

4. We all realize that finding enough time for professional development is a challenge for teachers. If we accept that learning from others in the field is a key way for you to progress as a teacher, can you suggest ways we can help you to foster relationships with others knowledgeable in EFL education including your fellow alumni?

5. If you haven't already done a Masters' degree, tell us what you think you would like to learn from doing one? 


\section{Appendix C}

\section{Survey Results}

\section{Part 1: About the Newsletter}

Question 1: Have you read all the previous issues of the newsletter?

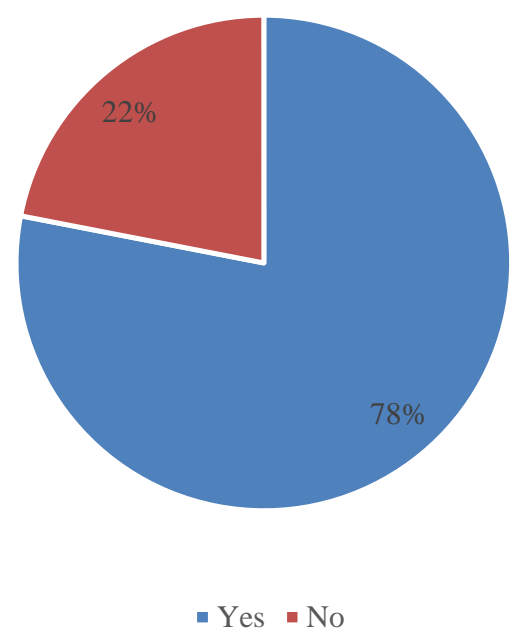

Question 2: Have you found the information to be relevant for your own development?

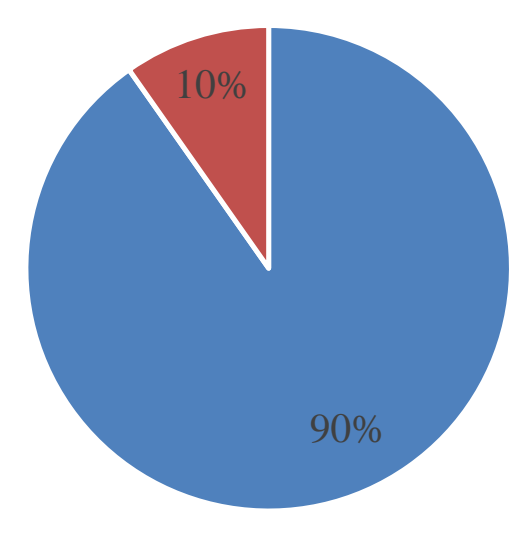

- Yes $\square$ No 
Charbonneau-Gowdy \& Magaña, 2020

Question 3: Have you found the newsletter to be useful for your own professional activity?

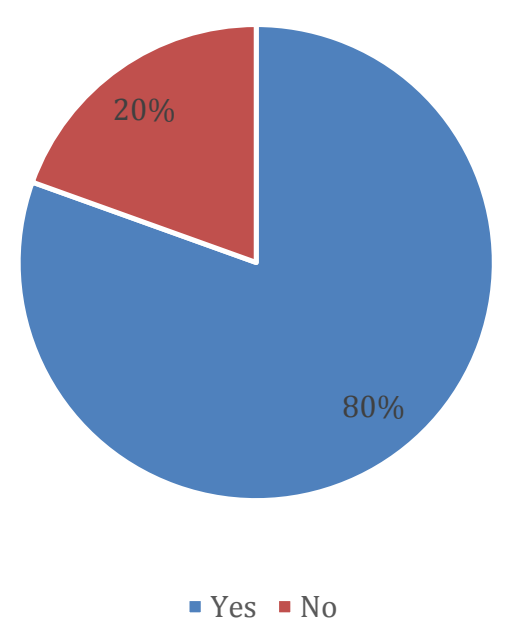

Question 4: Do you often read information associated with your professional activity?

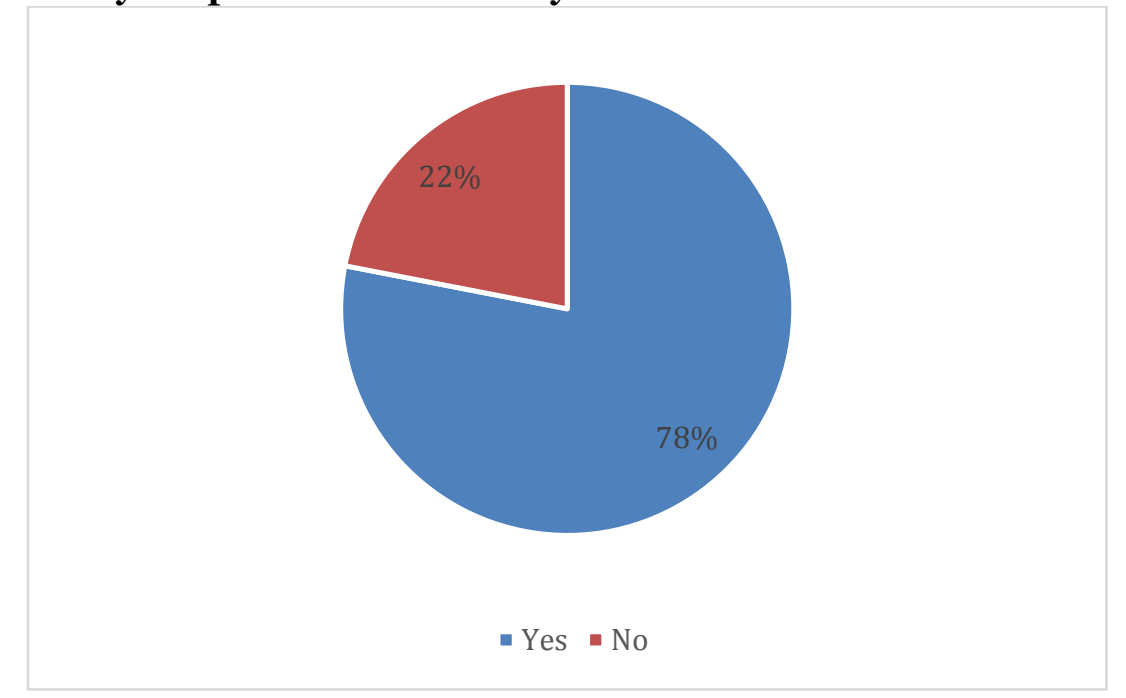

- Yes - No

\section{Open Access}

Question 5: While reading the newsletter do you feel as a member of our community?

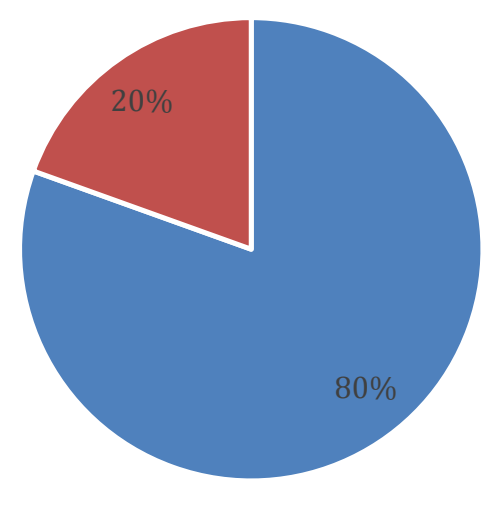

- Yes - No 
Part 2: About Your Professional Development

Question 6 : Do you have time for any professional development?

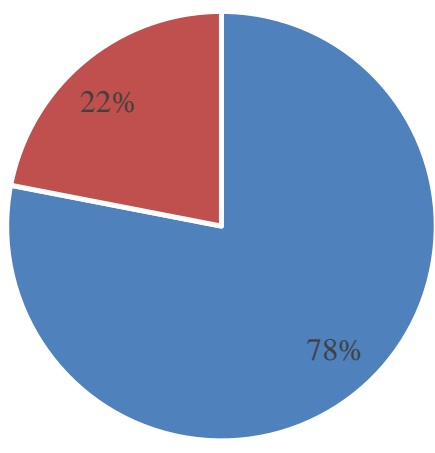

- Yes - No

Question 7: Have you in the past or are you currently contemplating pursuing any professional development activities?

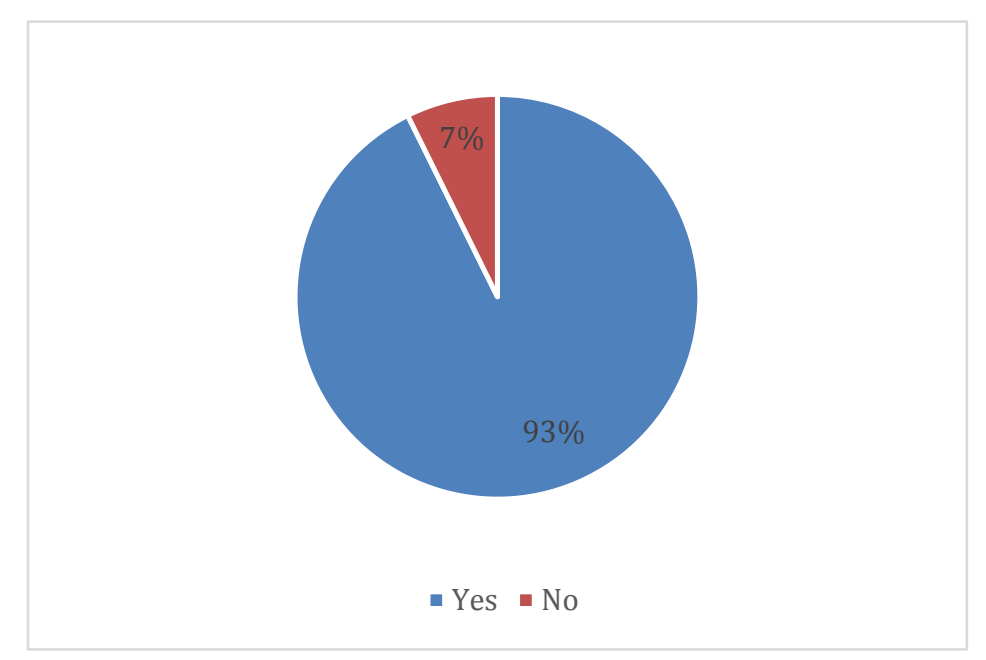

Higher Learning Research Communications
Question 8: Have you in the past or are you currently contemplating pursuing professional development in the form of graduate studies?

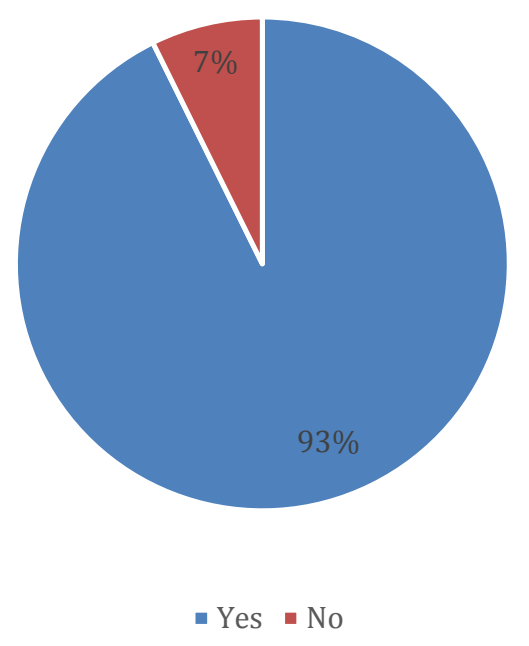


Question 9: Attending professional development events, such as conferences, seminars, workshops, and other activities, has a direct impact on my performance as a teacher.

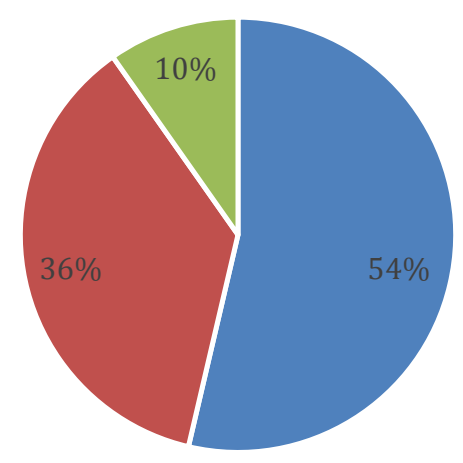

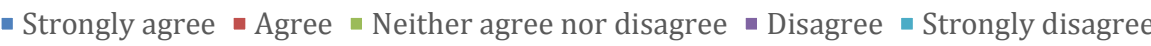

Question 10: Pursuing graduate studies is a fundamental step to take in order to grow as a professional.

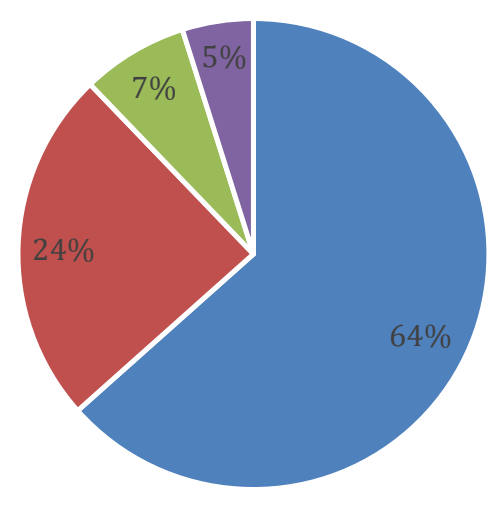

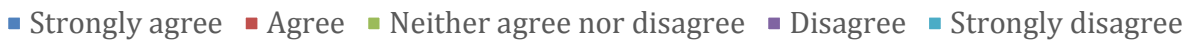


The Higher Learning Research Communications (HLRC), is a peer-reviewed, online, interdisciplinary journal indexed in Scopus, ERIC, JGATE and Directory of Open Access Journals (DOAJ). It is an open access journal with an international focus published by Walden University, USA. Its aim is to disseminate both high quality research and teaching best practices in tertiary education across cultures and disciplines. HLRC connects the ways research and best practice contribute to the public good and impact the communities that educators serve. $H L R C$ articles include peer-reviewed research reports, research briefs, comprehensive literature reviews, and books reviews. 